Ks. Stanisław LONGOSZ

(Lublin, KUL)

\title{
DRAMATYZOWANE HOMILIE O JANIE CHRZCICIELU I CHRZCIE CHRYSTUSA
}

Wczesnochrześcijańskie homilie $\mathrm{z}$ elementami dramatycznymi ${ }^{1}$, w zależności od stopnia ich rozwoju i udramatyzowania, można podzielić na trzy zasadnicze grupy: Homilie metryczne, zwłaszcza sugithy, tworzone głównie w Syrii przez jej ówczesnych największych poetów - św. Efrema $(† 373)$ i Narsesa $(\dagger 503)^{2}$; Półdramatyczne homilie pisane prozą, tworzone na Wschodzie, głównie po grecku, przez różnych autorów IV-VI wieku (np. Metody z Olimpu, Ps-Epifaniusz z Salaminy, Antypater z Bosry) parafrazujących i rozszerzających znacznie dialogi biblijne i dostarczających okazji do układania długich serii charetyzmów i pochwał ${ }^{3}$; Właściwe homilie dramatyczne ${ }^{4}$, oparte na wydarzeniach biblijnych, w których występują większe lub mniejsze dialogi i akcja, $z$ dodanymi nowymi fikcyjnymi dialogami oraz scenami pełnymi ruchu i dramatyzmu, które ze względu na treść można znów podzielić na: homilie o zwiastowaniu i wątpliwościach św. Józefa ${ }^{5}$, homilie o zstąpieniu

${ }^{1}$ Ich charakterystykę zob. S. Longosz, Zalażki dramatu chrześcijańskiego w literaturze patrystycznej, RH 44 (1996) z. 3, 263-273, spec. 268-271; lub tenże: I germi del dramma cristiano nella letteratura patristica, „Studia Patristica” 31 (1997) 60-61.

${ }^{2}$ Szczegółowe omówienie ich przykładów (4) zob. S. Longosz, Pótdramatyczne homilie patrystyczne, w: W poshudze stowa Bożego. Księga Pamiątkowa ks. J. Kudasiewicza, Kielce 1997, 424431.

${ }^{3}$ Szczególowe omówienie ich przykładów zob. tamże s. 431-437.

${ }^{4} \mathrm{Z}$ nowszej literatury na ich temat zob.: J. Kecskemati, Doctrine et drame dans la prédication grecque, „Euphrosyne” 21 (1993) 29-68; taż, Personnages tragiques et personnages comiques dans les homélies dramatisées des prédicateurs grecs, „Euphrosyne” 22 (1994) 45-61; taż, Deux caractéristiques de la prédication chez les prédicateurs pseudo-chrysostomiens: la répétition et le discours fictif, „Rhetorica” 14 (1996) 15-36; taż, L' homélie dramatisée dans la prédication grecque, „Connaissance des Pères de l' Eglise" (= CPE) 1999, nr 74, 20-34; taż, Exégèse chrysostomienne et exégèse engagée, „Studia Patristica” 22 (1989) 136-147; L. Brottier, Le prédicateur émule du prophète ou rival de l' acteur? Jean Chrysostome: un pasteur déchiré entre ses auditeurs et son Dieu, CPE 1999, nr 74, 2-19.

${ }^{5}$ Ich szczególowy wykaz z lokalizacją zob. Longosz, I germi del dramma cristiano, s. 67-68; G. La Piana, Le rappresentazioni sacre nella letteratura bizantina, Grottaferrata 1912, 105-127; Kecskemati, Personnages tragiques et comiques, s. 51-52. 
Chrystusa do piekieł oraz uwolnieniu stamtąd patriarchów i sprawiedliwych ${ }^{6}$, homilie o św. Janie Chrzciciclu i chrzcie Chrystusa ${ }^{7}$, homilie o cudach Chrystusa (np. Kananejka, ślepy od urodzenia, umierający sługa setnika, płacząca wdowa $z$ Nain $)^{8}$, a także homilie o dramatycznych wydarzeniach Starego Testamentu (np. grzech Adama i Ewy, Kain i Abel, Sara i słudzy) ${ }^{9}$. Całą powyższą tematykę ze względu na występujące w niej postacie usiłowano niekiedy przyporządkować zgodnie $z$ tradycją starożytną albo do tragedii (jak np. te ostatnic ze Starego Testamentu), albo do dramatów komediowych (np. bogaty młodzieniec, Zacheusz) ${ }^{10}$, albo nawet do mimu (np. bogacz, który planuje poszerzać swoje spichlerze ${ }^{11}$. Poprzez dramatyzowanie powyższych wątków biblijnych kaznodzieja przybliżał je niewątpliwie i ułatwiał ich zrozumienie słuchaczom starożytnym, przywyklym na codzień do oglądania i słuchania dramatów, ale z drugiej strony przez dołączanie do nich zmyślanych dialogów, scen i powiedzeń oraz ich teatralizacji desakralizował Pismo święte. Celem homiletykadramaturga stawało się $\mathrm{z}$ czasem nie uczenie słów i treści biblijnych, ale odtwarzanic jak najwiernicj postaci biblijnych; troska dydaktyczna ustępowała powoli ambicji estetycznej. Zamiast przekonania i pouczenia słuchaczy, mówca chce ich za sobą porwać i oczarować ${ }^{12}$. W ten sposób rodzil się powoli z ożywionej akcją dialogowanej homilii dramat chrześcijański. W naszym przyczynku chcemy tym razem przybliżyć na dwóch przykładach udramatyzowane homilie o Janie Chrzcicielu i chrzcie Chrystusa, z czym się również lączy Jego kuszenie.

Chrzest Jezusa w Jordanie był częstym i wdzięcznym tematem komentarzy Ojców Kościoła, zwłaszcza na Wschodzie w dniu Epifanii. Opisane przez ewangelistów podczas niego dialogi, sceneria i wydarzenia, zachęcały kaznodziejów nic tylko do ich zwykłego objaśniania, ale do ich rozbudowywania i dramatyzowania. Nic więc dziwnego, że tego rodzaju homilii starożytność

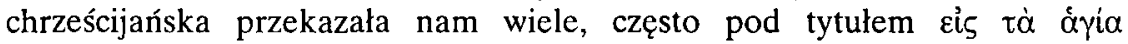

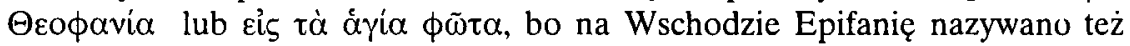
dniem świateł ( $\dot{\alpha} \gamma \dot{i} \alpha \phi \tilde{\omega} \tau \alpha)$ ze względu na zwyczaj zapalania w tym dniu w kościołach wielu świateł, symbolizujących światło Ducha Świętego, wylewa-

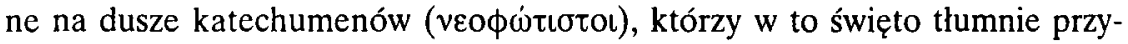

${ }^{6}$ Ich szczegółowy wykaz z lokalizacją zob. Longosz, I germi del dramma cristiano, s. 66-67; La Piana, Le rappresentazioni sacre, s. 79-105.

${ }^{7}$ Ich wykaz z lokalizacja zob. Longosz, I germi del dramma cristiano, s. 66; La Piana, Le rappresentazioni sacre, s. 72-79; Kecskemati, Doctrine et drame dans la prédication grecque, s. 4042, 34-38.

${ }^{8}$ Por. Kecskemati, Personnages tragiques et comiques, s. 53-56.

${ }^{9}$ Por. tamze, s. 46-50.

${ }^{10}$ Por. tamże, s. 56-58.

11 Por. tamzie, s. 58-60.

12 Por. tamże, s. 45-46. 
jmowali chrzest. Wśród wielu późniejszych homilii poświęconych temu tematowi, a zawierających w sobie wiele elementów dramatycznych, można m.in. wymienić dwie homilie pseudochryzostomiańskie: In Joannem praecursorem ${ }^{13}$ i In S. Theophaniam seu baptismum Christi ${ }^{14}$, przypisywana Teodotowi z Ancyry $(\dagger 446)$ Homilia in baptisma Domini ${ }^{15}$, przypisywana najpierw Grzegorzowi Cudotwórcy (210-270), potem Janowi Chryzostomowi, a będąca najprawdopodobniej dzicłem patriarchy Grzegorza z Antiochii (570-593) Homilia in $S$. Theophania ${ }^{16}$, czy wreszcie jedna z wielu udramatyzowanych homilii Pseudo-Euzebiusza Aleksandryjskiego Sermo de baptismo ${ }^{17}$. Z tych homilii do analizy wybieramy dwie ostatnie, z których pierwszą omówimy szczegółowiej, drugą ogólniej, ale przytoczymy w całości jej przekład.

Przypisywana Grzegorzowi Cudotwórcy Homilia na świẹta Teofanię ${ }^{18}$ Grzegorza z Antiochii cieszyła się zapewne dużym powodzeniem, bo zachowała się nie tylko po grecku, ale i po łacinie oraz w wersji syryjskiej i starosłowiańskiej $^{19}$. O przypisaniu jej patriarsze antiocheńskiemu zadecydowały przede wszystkim zawarte w niej, zwłaszcza w drugiej części mowy Jana, nauka i wyrażenia, zdradzające późniejsze teologiczne dyskusje i język, które nie mogły być znane Grzegorzowi Cudotwórcy. Kaznodzieja na jej wstępie przypomina słuchaczom, że są w okresie Bożego Narodzenia, zachęca ich jednak, by przenieśli się myślowo razem z Jezusem z Galilei do Judei, by tam oglądać Jana udzielającego chrztu:

„Przejdźcie wszyscy z Galilei do Judei i dołączmy się do Chrystusa [...] podążmy w myśli nad Jordan, i zobaczmy, jak Jan Chrzciciel chrzci Tego, który chrztu nie potrzebuje" (1172D).

Ten syntetyczny opis wystarcza, by określić miejsce sceny w umysłach słuchaczy, którzy znaleźli się w Judei, nad brzegiem Jordanu i oglądają Jana, udzie-

${ }^{13}$ Por. CPG 4521, PG 50, 801-806.

${ }^{14}$ Por. CPG 4522, PG 50, 805-808; Kecskemati, Doctrine et drame dans la prédication grecque, s. 41.

${ }^{15}$ Por. CPG 6135: M. Aubineau, Une homélie grecque inédite attribuée à Théodote d' Ancyre sur le baptême du Seigneur, w: Diakonia Pisteos. Mélanges J.A. de Aldama, Granada 1969, 6-30, tekst s. 12-20.

${ }^{16}$ Por. CPG 7385, PG 10, 1177-1190 lub PG 88, 1871-1884, PG 64, 33-38 (Ps-Chrysostomus); na temat jej autentyczności zob. S. Haidacher, $Z$ u den Homilien des Gregorius von Antiochia und des Gregorius Thaumaturgus, ZKTh 25 (1901) 367-369; J.A. de Aldama, Repertorium pseudochrysostomicum, Paris 1965, n. 27; La Piana, Le rappresentazioni sacre, s. 73-75; Kecskemati, Doctrine et drame dans la prédication grecque, s. 40.

17 Por. CPG 5520, PG 86, 372-380; G. Lafontaine, Les homélies d' Eusèbe d' Alexandrie, Louvain 1966, 132; M. van Esbroeck, Les plus anciens homéliaires georgiens, Louvain-La-Neuve 1975, s. 108-109 i 172.

${ }^{18}$ Por. PG 10, 1177-1190.

${ }^{19}$ Por. PG 1865-1872 (lac.); J.M. Sauget, OCP 27 (1961) s. 416, n. 10; Makarij, Januarius: Velikija Minei Cetij sobrannyja vserossijskim mitropolitom Makariem, St. Petersburg 1868, 339-438. 
lającego chrztu pokutnikom. $\mathrm{Z}$ zebranego tłumu wyłania się Jezus, a temat dalszej akcji kaznodzieja zapowiada wersetem biblijnym: „Wtedy przyszedł Jezus z Galilei nad Jordan do Jana, żeby przyjąć chrzest od niego" (Mt 3, 13). Niewidzialny chór zdaje się komentować krótko ten werset, wychwalając miłość Jezusa, który się uniża przez zmieszanie się z tłumem i prośbę o chrzest, jak pospolity grzesznik:

"Co za pokora Pana i skromność umysłu! Co za łaskawość, Król niebieski przychodzi do swego poprzednika, nie wysyłając wcześniej hufców aniolów ani poprzedzających go pustów ani bezcielesnych mocy [...] jako jeden z thumu przychodzi do niego. Zbawiciel siebie samego zalicza do więźniów, Sędzia stawia się wśród winnych, Dobry Pasterz dołącza się do zagubionych owiec, który z powodu błądzącej owcy zstąpił z nieba, ale nie opuścił nieba" (1180A).

Jan spostrzega Jezusa i ogarnia go wzruszenie; kaznodzieja opisuje jego gesty i pełne zakłopotania zachowanie oraz przytacza jego długą refleksyjną mowę, którą można podzielić na trzy części poprzedzone trzema wersetami biblijnymi.

„To ja potrzebuję chrztu od Ciebie, a Ty przyszedłeś do mnie” (Mt 3, 14). Jan deklaruje, że on jako ubogie i pokorne stworzenie, nie odważy się nigdy podnieść swej ręki i ochrzcić swego Stwórcę:

„Co czynisz, Panie? Dlaczego zmieniasz porządek rzeczy? Dlaczego ze sługami od swego sługi domagasz się tego, co przynależy sługom? Dlaczego chcesz otrzymać to, czego nie potrzebujesz? Dlaczego tak wielką laskawością i pokorą mnie slugę swego obdarzasz?" (1180BC).

Serią kolejnych antytez kontynuuje swój wywód:

„Swiatlo potrzebuje słońca, a nie słońce światła; glina jest kształtowana przez garncarza, a nie garncarz przez glinę; stworzenie ożywiane jest przez Stwórcę, a nie Stwórca przez stworzenie; chory jest leczony przez lekarza, a nie lekarz przez chorego; ubogi pożycza u bogatego, a nie bogaty u ubogiego" (1180C).

Jan dalej prowadzi długi dialog z sobą uświadamiając sobie własną niegodność i nie rozumiejąc, dlaczego Chrystus-Bóg, o którym wiele wiedział, chce być ochrzczony przez niego.

Druga część wewnętrznego dialogu Jana Chrzciciela dotyczy wersetu: „Któremu ja nie jestem godzien odwiązać rzemyka u Jego sandała” (J 1, 27). Chrzciciel znów najpierw wyraża swoją niegodność:

„Jakże ja odważę się dotknąć niepokalanego czubka Twojej głowy? W jaki sposób wyciągnę swoją prawicę nad Tobą, który rozpostarleś niebo jak skórę i ustanowiłeś ziemię nad wodami? [...] w jaki sposób mam oświecić samo światło" (1184A).

Następnie zamienia się w teologa, by wyznać swoją wiarę w różne prawdy teologiczne, dotyczące bóstwa Jezusa, Jego natury i Jego relacji z Ojcem. Ale 
i w tym passusie nie brak żywości dramatycznej, wywołanej pytaniami kierowanymi do Jezusa:

„W imię kogo mam Cię ochrzcić? Czy w imię Ojca? - przecież Ty masz całego Ojca w sobie i cały jesteś w Ojcu. Czy w imię Syna? - przecieź oprócz Ciebie nie ma innego Syna Bożego z natury. Czy w imię Ducha Świętego? - przecież On jest zawsze razem $z$ Tobą, jako Ci wspólistotny, tej samej woli i myśli, równy władzą i czcią, z Tobą od wszystkich przyjmuje uwielbienie. Ty mnie ochrzcij, Panie, jeśli zechcesz, ochrzcij mnie chrzciciela" (1184B).

Tematem trzeciej części mowy Jana Chrzciciela jest kolejny werset biblijny: „Oto Baranek Boży, który gładzi grzech świata" (J 1,29). I tutaj, podobnie jak w poprzedniej części mowy, kaznodzieja najpierw przyzywa niewidzialny chór wyrażający myśl ogólną:

„I ty rzeko Jordanie, pędź ze mną chóry, wychwalaj i porusz swe fale do należytego tańca [...] góry i pagórki, wzgórza i doliny, morza i rzeki, blogoslawcie Panu przekraczającemu wody Jordanu" (1184C).

Tym to wzniosłym słownictwem wzywa rzeczy i stworzenia do radości, bo zbawienie świata jest blisko. W odpowiedzi na to wkracza Chrystus który mówi: „Pozwól teraz, bo tak godzi się nam wypełnić wszystko, co sprawiedliwe" (Mt 3, 15). Zobowiązuje On jednak Chrzciciela do milczenia mówiąc, że nie nadszedł jeszcze czas ujawnienia Jego bóstwa:

„Zachowaj, Chrzcicielu, na pewien czas milczenie. Zrozum to, czego chcę, ale nie dociekaj ciekawie, czego chcę" (1184D).

Motywem zaś, dla którego Jezus nie chce być rozpoznany, jest obawa, by tyran, czyli diabeł, nie podejrzewał niczego:

„Nie zdradzaj jeszcze mojego bóstwa, nie ogłaszaj jeszcze swoimi ustami mojego królestwa, aby się o nim nie dowiedzial tyran i nie powziąl zamysłu, który przeciw mnie podjął [...] pozwól mi wypełnić plan i postanowienia, z powodu których przybyłem na ziemię" (1184D-1185A).

Chrystus długo jeszcze uzasadnia powody swego ukrywania się i ukrytego na ziemi postępowania, ale w końcu prosi dalej o chrzest:

„Trzeba, żebym teraz tym chrztem został ochrzczony, a później jako wspólistotny Trójcy udzielał chrztu wszystkim ludziom. Udziel mi, Chrzcicielu, dyspensy, wyciągnij nade mną swą prawą rękę, zanurz mnie w falach Jordanu [...]. Udziel mi chrztu, jak Dziewica mleka. Dotknij mej głowy, którą czczą i uwielbiają Serafini" (1186D).

W odpowiedzi na te słowa Jan ogarnięty tajemnicą i ujęty prośbą Chrystusa, „wyciąga powoli swoją drżącą prawą rękę i chrzci Pana” (1188B). 
Grupa jednak stojących w pobliżu żydów, którzy słyszeli słowa Chrzciciela, zaczęła szemrać miçdzy sobą:

"Czy darmo podejrzewaliśmy, że jednak Jan jest większy i lepszy od Jezusa. Czy darmo sądziliśmy, że on jest ważniejszy? Czy sam chrzest Chrzciciela nie świadczy o tym, kto tu jest ważniejszy? Czy nie ten, który chrzcił?, a ten, który został ochrzczony, czy nie jest niższy?" (1188B).

Te wątpliwości żydów zostały jednak rozwiane przez przerażający grzmot, pojawienie się Ducha Świętego w postaci gołębicy i potężny głos Ojca z nieba "Ten jest Syn mój umiłowany, w nim sobie upodobałem” (Mt 3, 17):

„To Jezus, a nie Jan. To ten ochrzczony, a nie ten, który chrzcił: to ten zrodzony ze mnie przed wiekami, a nie ten zrodzony z Zachariasza; to ten zrodzony według ciała z Maryi, a nie ten, który wbrew nadziei pojawił się z Elżbiety" (1188C).

Kiedy zamilkł głos Ojca, kaznodzieja komentuje krótko zaistniałe na scenie wydarzenia i kończy tradycyjnie homilię mówiąc:

„Wszyscy poznali różnice między Stwórcą a stworzeniem, między królem a żołnierzem, między twórcą a dzielem, a umocnieni w wierze zbliżyli się przez chrzest Jana do Tego, który chrzci w ogniu i Duchu" (1189A).

Wydaje się, że dramatyczna forma tej homilii jest wystarczająco rozwinięta. Występuje w niej 6 postaci; Jezus, Jan Chrzciciel, głos Boga, thum żydów, chór i mówca, którzy mają swoje poszczególne, dobrze sprecyzowane role. Jasno są również określone miejsce i akcja. Dialogi mimo rozwlekłości i suchej treści teologicznej niektórych części mowy Jana, zachowują zawsze swą żywość dramatyczną, jaka przystoi świętej recytacji, a byłaby wręcz absurdalna w zwykłej homilii. Akcja dramatu jest oparta na ogólnych liniach opowiadania ewangelicznego. Autor, jeśli nawet oddala się nieco od ewangelicznego tekstu w amplifikacji dialogu, wprowadza w akcję nowe elementy lub nowe osoby w postaci grupy szemrających żydów, trzyma się w zasadzie biblijnego tekstu. Są to jednak pierwsze kroki w kierunku coraz większego uniezależniania się od tekstu biblijnego, zbierające i uwzględniające także inne elementy, pochodzące $z$ tradycji ludowej i apokryficznej, bez ograniczania się wyłącznie do uświęconych kanonicznie treści biblijnych.

Druga omawiana przez nas Homilia o chrzcie Pseudo-Euzebiusza Aleksandryjskiego ${ }^{20}$, nieznanego nam bliżej autora wysoce udramatyzowanych homilii z końca $\mathrm{V}$ lub początków VI wieku ${ }^{21}$, w pierwszej swej części nie jest

${ }^{20}$ Por. PG 86, 372-380.

${ }^{21}$ Podstawowe informacje o Pseudo-Euzebiuszu Aleksandryjskim zob. DPAC I 1284-1285 (S.J. Voicu); DSp IV/2 1686-1687 (J. Darrouzes); DThC V/2 1526-1527 (F. Nau); LAChL 209 (B. Windau); SWP 142. Obszerniejsze dane wraz z jego bibliografią i polskim przekładem 6 jego udramatyzowanych homilii zob. w następnym tomie „Vox Patrum”. 
niczym innym, jak streszczeniem wyżej omówionej: te same tematy opowiedziane w tym samym porządku, ta sama sytuacja, te same pojęcia, kilka razy nawet te same słowa, ale wszystko w skrócie i bez powtórzeń. Jak w powyższej tak i w tej homilii, Jan wychodzi naprzeciw Jezusa wzbraniając się, że nie może Go ochrzcić: „Nie mogę, nie śmiem glinianej ręki włożyć na nieśmiertelną głowę" (373B). Także tu Chrzciciel przytacza porównanie garncarza i gliny: „Glina potrzebuje ręki garncarza, a sługa potrzebuje pomocy pana" (373B). Również Jezus podobnie odpowiada nakazując Janowi milczenie, ponieważ nie chce, by nieprzyjaciel odkryl jego bóstwo: „Nie chcę, by ujawniono, kim jestem" (373B). Potem następuje w kilku krótkich zdaniach opis sceny chrztu z głosem Ojca z nieba.

Po tej części pojawia się nowa postać - diabel, który zobaczywszy chrzest Chrystusa i wydarzenia $z$ nim związane, nie mógł się uspokoić i pełen podejrzeń „zatrwożyl się i stracił spokój” (376A). I teraz następuje drugi akt dramatu: diabeł się reflektuje i w dlugiej rozmowie z sobą wyraża niezadowolenie i strach, bo nie wie, kim On jest, czy nie jest czasem obiecanym Mesjaszem. By się o tym przekonać, postanawia Go kusić: uległość czy opór pokusie ujawni, czy jest on zwykłym człowiekiem, czy obiecanym Mesjaszem. Scena kuszenia odbywać się jednak będzie, zgodnie $z$ tekstem św. Mateusza $(4,1-11)$, w trzech miejscach, których kolejność kaznodzieja dla osiągnięcia lepszego efcktu dramatycznego celowo zmienia (Mateusz: pustynia, szczyt świątyni, wysoka góra; kaznodzieja: wysoka góra, pustynia, szczyt świątyni). Ze względu na dołączony niżej przekład całej tej homilii, nie będziemy tu szczegółowo omawiać poszczególnych miejsc kuszenia, ale ograniczymy się tylko do jej krótkiej charakterystyki.

Nie ma wątpliwości, że omawiane wyżej homilie w pierwszej części zależą od siebie, czego dowodzą, jak zaznaczaliśmy, prawie identyczne obrazy, pojęcia i wyrażenia. Możemy z dużą dozą prawdopodobieństwa przypuszczać, że także sceny kuszenia, spotykane jedynie w homilii pseudoeuzebiańskiej, były kiedyś przedstawione obszerniej w homilii gregoriańskiej, choć także w tej była wzmianka diabła jako motywu, dla którego Jezus nakazuje Janowi milczenie - by ukryć swe bóstwo: Jezus zapowiada wyraźnie, że diabeł przyjdzie go kusić i że walka ta jest bliska.

Homilia pseudoeuzebiańska scenę chrztu Chrystusa przedstawia w streszczeniu, a rozbudowuje sceny kuszenia, których kolejność autor, jak wspominaliśmy, celowo zmienia, aby przez umieszczenie Chrystusa na szczycie świątyni i jego odpowiedź na pokusę szatana uzyskać na zakończenie dramatu deklarację, w której Jezus prawie że ujawnia swoje bóstwo, a któremu chór odpowiada doksologią. Pięknic przedstawiona jest scena kuszeń, zarówno pod względem opisu różnych ich miejsc, jak i pod względem kontrastu języka - gadatliwości diabla oraz uroczystych i poważnych odpowiedzi Jezusa. Wyjątkowo udramatyzowana i psychologicznie podbudowana jest również rozmowa diabła z samym sobą: jego niepokój, lęki, strach, wyrażone serią eksklamacji, z jednej strony go 
ośmieszają, a z drugiej wprowadzają zapewne wśród słuchaczy nieco dobrego humoru. Obydwie te homilie o Janie Chrzcicielu, chrzcie i kuszeniu Chrystusa, pełne dialogów i niezwykłych wydarzeń, są bez wątpienia kolejnym mocnym etapem w procesie krystalizowania się dramatu chrześcijańskiego.

\section{HOMILIAE DRAMATICAE DE JOANNE BAPTISTA ET BAPTISMO CHRISTI}

(Argumentum)

Hac in brevi dissertatiuncula explicantur duae dramaticae homiliae: false attributa Gregorio Thaumaturgo Homilia in S.Theophania (CPG 7385) patriarchae Gregorii Antiocheni et Homilia de baptismo (CPG 5520) Pseudo-Eusebii Alexandrini, quae iuxta auctorem constituunt validum momentum in processu formandi dramatis christiani; uti appendix proponitur prima Polonorum translatio homiliae pseudo-eusebianae de baptismo.

\section{HOMILIA O CHRZCIE PAŃSKIM PSEUDO-EUZEBIUSZA ALEKSANDRYJSKIEGO*}

Skoro wczoraj wysłuchaliście $\mathrm{z}$ tak wielkim zainteresowaniem i podziwem kazania o Bożym Narodzeniu, zaczniemy teraz mówić również o chrzcie Pańskim. Dzisiaj zatem powiemy sobie, jak Słowo przystąpiło do chrztu, po ilu latach od narodzenia z Dziewicy Pan ochrzcil się nad Jordanem, uświęcając naturę wody oraz darując całemu światu oczyszczenie, odkupienie i przebaczenie grzechów; wówczas też objawil się ludowi. Zanim bowiem ochrzcil się, nie czynił znaków i nie ukazywał się światu, mówią zaś czterej ewangeliści, że dopiero po tym, jak się ochrzcil, zaczął czynić znaki i cuda wśród ludu. Ochrzcił się natomiast nie dlatego, że sam potrzebował oczyszczenia, gdyż nie popełnił grzechu, a w ustach Jego nie było podstępu, ale ochrzcil się dla nas, aby darować nam zapowiedź naszego chrztu, w wodach którego podepczemy diabła. Jeśli bowiem po przyjęciu chrztu zachowamy czystość duszy, mamy moc podeptać go zgodnie z tym, co Pan powiedział: „Oto dałem wam moc stąpania po wężach i skorpionach i po całej potędze nieprzyjaciela" (Łk 10,19). Popatrz, kochany, w jaki sposób mówiąc o stąpaniu po wężach i skorpionach oznajmił, że dał nam moc nad całą potęgą nieprzyjaciela. Wąż ma żądło $w$ języku, a skorpion w ogonie, czyli Pan dał nam moc zdeptania całej jego siły, władzy i potęgi, od glowy aż do ogona.

\footnotetext{
* Przekładu z tekstu greckiego w PG 86, 372-380 dokonała Tatiana Krynicka.
} 
Pan przystąpił do chrztu po to, by zniweczyć potęgę wroga, objawić, że jest Synem Bożym i aby świat Go poznał. Nie sam o sobie powiedział, że jest Synem Bożym, lecz dal o tym świadectwo Jan, wskazując palcem i powiadając: „Oto Baranek Boży, który gładzi grzechy świata" (J 1, 29). Poza tym, gdy przyszedl, aby się ochrzcić Jan sprzeciwił się temu mówiąc: „Ja potrzebuję, abyś Ty mnie ochrzcil, a Ty przychodzisz do mnic?" (Mt 3,14). Nie mogę, powiada, nie śmiem glinianej ręki włożyć na nieśmiertelną glowę. Lękają się Ciebie Cherubini, Serafini śpiewają $\mathrm{Ci}$ hymny, drżą przed Tobą niebiosa, widząc Cię trzęsie się ziemia, poruszają się góry, wszystko zamiera ze strachu w obliczu Twojej potęgi. Jakże ja śmiertelnik, ośmielę się dotknąć Twej nieśmiertelnej głowy? Glina przecież potrzebuje ręki garncarza, a sługa pomocy pana. Dlatego, Panie, nie ośmielę się wylać wody na Twoją nieśmiertelną glowę. Na to Pan rzekł do niego: „Przestań teraz, bo należy nam wypełnić wszystko co sprawiedliwe" (Mt 3, 15). Mówiąc to Pan chciał niejako powiedzieć: „Nie chcę, by teraz zostało ujawnione, kim jestem. Po to bowiem przyoblekłem się w ciało, po to stalem się człowiekiem, aby wypełnić całą sprawiedliwość. Zanim przyszedłem w ciele, morze widząc Mnie uciekało, góry i pagórki podskakiwały, sam Jordan popłynąl wstecz. Dlatego stałem się czlowiekiem, aby również Jordan przyjąl Mnie bez strachu. Oto jestem, nie wahaj się, czyń to, co do ciebie należy. Ale nie tylko ty winieneś dać o Mnie świadectwo, ponieważ w takim przypadku ludzie myśleliby, że czynisz to, aby mi się przypodobać. Trzeba, by również Ojciec dal o mnie świadectwo z góry, by zstąpił Duch Święty: wówczas świat pozna, kim jestem, a ci, którzy do Mnie należą, rozpoznają Mnie". Dopiero wtedy Jan ochrzcił Go w Jordanie, a Duch Święty zstąpił w postaci gołębicy i pozostał na Nim. Rozlegl się również głos z niebios mówiący: „Ten jest mój Syn umiłowany, w którym mam upodobanie" (Mt 4, 17).

Gdy diabeł usłyszał świadectwo Jana mówiącego: „Oto Baranek Boży, który gładzi grzechy świata" (J 1, 29), gdy zobaczył zstępującego z wysokości Ducha Świętego, gdy doszedł do jego uszu glos Ojca mówiącego z niebios: „Ten jest mój Syn umiłowany" (Mt 4,17), zatrwożył się i stracił spokój. Zanim bowiem Zbawiciel przystąpił do chrztu, diabeł nie wiedział, kim On jest. Myślał, że Jezus to jeden spośród ludzi, gdyż wiedział, że urodzil się z kobiety, ale nie rozumial planu Boga, który postanowil, że z powodu upadku Ewy Jego Syn zrodzi się z Dziewicy, aby ród niewieści został uwolniony od przekleństwa. Nikczemny diabeł widział Go, jak ssał pierś [matki] i sądził, ze jest tylko zwykłym dzieckiem, zrodzonym z mężczyzny i kobiety, a nie wiedział, że Słowo Boże stało się ciałem i zamieszkało między nami, że Dawca manny ze względu na nas karmiony był mlekiem. Widział też, jak Pan żywił się chlebem, lecz nie domyślał się, że był On tym, który daje pożywienie wszelkiej żywej istocie. Nie przypuszczal, że przez chrzest Pan strąci go wraz z jego demonami do ognia piekielnego, podobnie jak przedtem pogrążył $w$ morskiej otchłani faraona i jego wojsko. Widział Go siedzącego na kolanach matki, lecz nie domyślal się, że jest On tym, który zgodnie z zapowiedzią Izajasza zasiądzie na wysokim, wzniosłym trohie: „Zobaczyłem Go siedzącego i Serafini wokół Niego śpiewali i mówili: "Święty, święty, święty, Pan Bóg Zastępów, pełne jest niebo i ziemia Jego chwały»" (Iz 6, 1-3). Widział też diabeł, ze jako jeden spośród ludzi 
przystępował do chrztu i sądził, że jest tylko czlowiekiem, a nie przyszło mu do glowy, że jest tym, który będzie chrzcił świat Duchem Świętym i ogniem.

Widząc to wszystko, patrząc na Pana przystępującego do chrztu, diabel nie pomyślał, żc Bóg zamieszkał w człowieku. Dopóki Pan nie ochrzcił się, diabeł o nic się nie martwił. Ani razu przecież nie podchodził do Niego, by Go wystawić na pokuszenie i dowiedzieć się kim jest, ale spodziewal się, że wraz $\mathrm{z}$ innymi zamknie go również w pickle. Lecz gdy uslyszal, jak już powiedziałem, świadectwo Jana nad Jordanem, gdy usłyszał głos Ojca z góry i zobaczył zstąpienie Ducha Świętego, zatrwożył się i powiedział sam sobie: „Kimże On jest? Wiem, że jest urodzony z Marii, znam też jego ojca rzemieślnika, jakże teraz mogę słuchać o Nim podobnych rzeczy? Czyż czasem nie jest to Chrystus? Czyż nie jest to ten, który ma odkupić świat? Czyż nie jest to Słowo, które było na początku, któremu nie byłem posłuszny i zostałem zrzucony na ziemię? Nie wierzę, żeby ten, który własnymi rękami ulepił człowieka przywdział ludzkie ciało. Cóż więc mam czynić? Jak mogę się dowiedzieć, czy to na pewno jest On? A jeśli tak, jeśli to On, to przyszedł na świat, aby zmierzyć się ze mną. W takim razie biada mi nieszczęsnemu, gdyż ustała moja moc, stępiły się moje żądła, osłabła moja siła!" Myśląc o tym wsżystkim i zawodząc diabel nie wiedział, co uczynić, aż wreszcie wpadł na pewien pomysł i powiedział sobie: „Zblizęe się do Niego i wystawię Go na próbę. Jeśli to właśnie On jest Synem Boga, przejrzy mnie i nie pozwoli, bym Go wodzil na pokuszenie, lecz swoim słowem mnie przepędzi. Jeśli zaś kusząc Go dowiem się, że nie jest Chrystusem, a Jan ośmielił się wydać o Nim takie świadectwo i mnie zasmucić, już ja mu pokażę, już ja go nauczę, by odtąd tak się nie wypowiadał! Swoją drogą chciałbym wierzyć, że Jan powiedział to od siebie i trochę się pocieszam tym, że tak mogło być, ale boję się tego głosu z niebios i drżę, że On naprawdę jest Chrystusem".

Wówczas Pan widząc, że diabeł bardzo się przestraszył, chciał uciekać i nie miał odwagi zbliżyć się do Niego, zacząl zachowywać się jak człowiek, pozwolił, by Go kusił i ukrył boskość swojej chwały. Kiedy zaś diabeł zauważyl, że Pan postępuje jak człowiek ożywił się nieco i zaczął Go wyśmiewać. Gdy zaś Pan oddalił się na wysoką górę, „pokazał Mu wszystkie królestwa świata, i rzekł do Niego: «To wszystko tobie dam, jeśli upadniesz przede mną i oddasz mi poklon»" (Mt 4, 8-9). Cóż ty mówisz, nikczemny diable? Obiecujesz Stwórcy wszechświata dać to, co stworzył? Proponujesz królestwo Panu panujących, który obdarza władców zbawieniem? „To wszystko tobie dam, jeśli upadniesz przede mną i oddasz mi pokłon (Mt 4, 8-9). Popatrz, kochany, na niegodziwy zamiar złośliwego czarta, popatrz, jaką pokusę uknuł. Wiedzial, że rodzaj ludzki od początku spragniony jest wladzy, dlatego wymyślił tę pokusę. Mówił sobie tak: ,Jeśli jest człowiekiem, to proponując Mu bogactwa sprowadzę Go natychmiast do mych stóp; jeśli natomiast jest nie tylko człowiekiem, lecz również Słowem Bożym, cóż, wówczas zobaczę, co mam czynić”. Pan natomiast poznal cel nieprzyjaciela, dlatego nie ujawniał swej boskości, ani nie czynić nic z tego, co ludzkie, lecz odpowiedział dwuznacznie i zamknął mu gębę mówiąc: „Jest napisane, Panu Bogu twemu będziesz oddawał pokłon, i Jemu tylko będziesz służyl" (Mt 4, 10). W ten sposób jednym zdaniem zniweczyl jego zamiar. Nie przepędził go jednak, ani nie dał mu żadnych zaleceń, lecz pozwolił mu dalej snuć swoje 
domysły. Diabeł natomiast po tym, jak nie otrzymal odpowiedzi, uciekł się do innego sposobu kuszenia. Gdy przemierzali pustynię, znowu przemówił do Pana: „Jeśli jesteś Synem Boga, powiedz, by te kamienie stały się chlebem" (Mt 4, 3); Pan bowiem pościł przez czterdzieści dni, a potem poczuł głód, nie w swoim bóstwie, lecz w swoim człowieczeństwie. Lecz diabeł nie wiedział o tym i rzekł: „Powiedz, by te kamienie stały się chlebem" (Mt 4,3). Bezwstydny diable, oczy wszystkich są w Nim utkwione, a On daje im pokarm we właściwym czasie, czyż nie mógłby On uczynić kamieni chlebem? Ten, który na pustyni zesłał Izraelowi z nieba jak deszcz mannę, czyż nie mógłby uczynić kamieni chlebem, o nikczemny diable? On, który rzekł, a niebo, ziemia, i całe stworzenie z niebytu powołane zostało do istnienia, czyż kamienie na Jego słowo nie stałyby się chlebem? Jasne, że stałyby się! Chce Cię jednak zwabić i pokonać, dlatego nie mówi, by kamienie stały się chlebem. Cóż więc Pan odpowiedzial diabłu? „Nie tylko chlebem żyje człowiek, lecz każdym slowem Boga" (Mt 4,4). Zobaczyl znów diabel, że nie otrzymał jasnej odpowiedzi, ale nie przestał Go jeszcze kusić. Bierze Go więc i idą do świętego miasta, gdzie wyprowadza Go na szczyt świątyni i mówi do Niego: „Jeśli jesteś Synem Boga, rzuć się stąd na dół" (Mt 4, 5-6). Wtedy dopiero Pan stwierdził, że diabeł zbyt długo Mu dokucza, uchylił rąbka swego bóstwa i zgromił go mówiąc: „Odejdź ode mnie, szatanie, nie będziesz wystawiał na próbę Pana Boga twego" (Mt 4, 7). Wówczas diabel odszedł i uciekł, gdyż nie zniósł ostrych słów wypowiedzianych przez Pana. Ze względu na nas Pan pozwolił diabłu, aby Go w ten sposób kusił. Mógł go przecież wcześniej przepędzić, lecz ukrył swe bóstwo, aby nieprzyjaciel nie uciekł i abyśmy mieli udział w zmartwychwstaniu, z tego też powodu był kuszony. Zachował milczenie, aby zwyciężyć diabła, a nas uwolnić od tego kuszenia, Jemu niech będzie chwała na wieki. Amen. 